\title{
Overcoming the business model transformation dilemma: exploring market shaping and stabilizing strategies in incumbent firms
}

\author{
Per Fohan Carlborg, Nina Hasche and Fohan Kask \\ Orebro Universitet Handelshogskolan, Orebro, Sweden
}

\begin{abstract}
Purpose - The purpose of this paper is to extend the knowledge on business model transformation (BMT) by developing an integrative framework for BMT dilemmas, including strategies for shaping and stabilizing market structures.

Design/methodology/approach - The study uses a case-based approach, with data from the Swedish electric utility industry.

Findings - The findings uncover practices related to both shaping and stabilizing market structure. The study contributes with insights for firms to overcome the BMT dilemma. Shaping strategies involve disruptive innovations while stabilizing strategies concerns incremental improvements in existing structures; by balancing these efforts, firms can find ways toward successful BMT.

Originality/value - With a focus on incumbent firms and the balancing act of BMT in a network, the study covers areas that have scarcely been addressed in the existing literature. Even though most business model literature has focused on shaping consumer markets, the need to consider BMT as a dual-directional process in an industrial context is emphasized in this study.
\end{abstract}

Keywords Innovation, Business strategy, Networks, Business model transformation, Market logic, Shaping, Stabilizing, Network

Paper type Case study

\section{Introduction}

In top strategic marketing and innovation-centric management journals, there is increasing interest in business model transformation (BMT) - moving from one business model (BM) to another - as an imperative for achieving a competitive edge (Foss and Saebi, 2018). In the industrial marketing literature, the re-conceptualization of BMs is seen as a key driver for competitive advantage (Matthyssens, 2019). Simultaneously, the BM's network aspects are increasingly acknowledged as essential aspects of this transformation (Jocevski et al., 2020; Klimanov and Tretyak, 2019; Palo and Tähtinen, 2011).

While market structures are disrupted, incumbents frequently experience situations where their BM, once wellfitted to the old market structure, loses its relevance (Hacklin et al., 2018; Pateli and Giaglis, 2005). Recent research has found that common responses to a lost relevance include either a complete replacement of the firm's old BM or an endeavor to incrementally add extra layers to the old BM while continuing "business as usual" in parallel (Hacklin et al., 2018). Despite the strategy chosen, BMT is always a significant risk, especially for industrial firms, as it means disruption to the firm's normalized practice, as well as organizational tensions from ambidexterity - the ability of an organization to manage the present market situation while at the same time explore new

The current issue and full text archive of this journal is available on Emerald Insight at: https://www.emerald.com/insight/0885-8624.htm

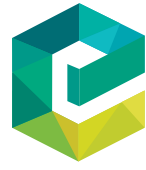

Journal of Business \& Industrial Marketing 36/13 (2021) 66-77

Emerald Publishing Limited [ISSN 0885-8624] [DOI 10.1108/JBIM-06-2020-0264] opportunities and respond to changes in the environment (Eltantawy, 2016; Koryak et al., 2018; O'Reilly and Tushman, 2008). Both the complete leap and the incremental strategy could, nevertheless, be successful to some extent and prior work has generated important insights about sound BMT strategies both on developing existing business and radically inventing new ones (Aspara et al., 2013). Recent works have also recognized how proactive BMT can change and disrupt the dominant market structure in different industries (Bidmon and Knab, 2018). Hence, it is shown that BMT can be proactively executed to induce structural market change and reactive as in response to stabilizing the existing market structure.

However, while much research emphasizes BM innovation (Chesbrough, 2010; Sosna et al., 2010) less is known about the BMT dilemma of balancing between the paradoxical tension of shaping a new market and, often in parallel, attempting to stabilizing already captured market positions (Kjellberg et al., 2015). For incumbents, this strategic dilemma appears in how to accelerate the transformation toward something new and potentially more viable for the future while remaining profitable throughout the transformation process and without ruining the investments made. Conversely, a framework that expands and

\footnotetext{
(C) Per Johan Carlborg, Nina Hasche and Johan Kask. Published by Emerald Publishing Limited. This article is published under the Creative Commons Attribution (CC BY 4.0) licence. Anyone may reproduce, distribute, translate and create derivative works of this article (for both commercial \& non-commercial purposes), subject to full attribution to the original publication and authors. The full terms of this licence may be seen at http://creativecommons.org/licences/by/4.0/legalcode
}

Received 5 June 2020

Revised 13 November 2020

12 January 2021

Accepted 20 January 2021 
integrates the knowledge of the BMT dilemma is still missing. More critical, from a practical standpoint, is that the balancing dilemma in BMT has not yet been explicitly linked to the overall strategy of the firm. In other words, facing different starting points, strengths and firm goals, executives have little strategic guidance from the literature that focuses either on accelerating transformation processes or squeezing profits from existing assets without tackling the dilemma of doing both in parallel.

Hence, this paper aims to extend the knowledge of BMT by developing an integrative framework for BMT dilemmas, including strategies for shaping and stabilizing market structures. The framework is developed by a case study that describes three attempts to move from one BM to another in the electric utility market. This in-depth, multi-source case study is based on both primary sources, including observations, field studies and interviews and secondary data such as annual reports, sales presentations and newspaper articles. By doing this, we contribute to a better understanding of how the two transformative movements are mutually important and dependent, especially for incumbents in established but changing markets. This study makes at least two contributions to the ongoing discussion on BMT. First, it develops a framework for balancing the dilemma by adopting marketshaping strategies and market stabilization strategies. Second, it provides managers with practical knowledge on how to coordinate resources in times of structural changes.

The article continues as follows: first, the theoretical background, framework and methodology are presented. Then, the analysis and conclusions are discussed.

\section{Frame of reference}

Even if the theoretical conceptualization of the BM is fragmented (e.g. a vision, a management idea, a strategy and the blueprint of the firm), the BM is a widespread concept, both theoretically and practically, as a metaphor of the firm's modus operandi (Osterwalder and Pigneur, 2010) - containing its resources and competencies, the organizational structure and the value proposition to the market (Demil and Lecocq, 2010).

\section{A BM:}

[...] describes the design or architecture of the value creation, delivery, and capture mechanisms [a firm] employs. The essence of a business model is in defining the manner by which the enterprise delivers value to customers, entices customers to pay for value, and converts those payments to profit (Teece, 2010, p. 172).

Traditionally, the BM has been viewed as a rather static concept, like a blueprint of the firm (Demil and Lecocq, 2010) and as a belonging of a single firm (Mason and Spring, 2011). Recently, however, the research interest has shifted toward a view of the BM as dynamic (Bohnsack et al., 2014; Foss and Saebi, 2018; Nyström and Mustonen, 2017) and interconnected (Jocevski et al., 2020). Hence, the BM is in this work characterized by "a meso-level value architecture that describes the value flow and dynamics of value creation, delivery and capture mechanisms at a network level" (Jocevski et al., 2020, p. 1062). The set of network actors includes customer, partners and other stakeholders in the system. However, it is also possible to understand BMs in business networks as subsets of larger systems. In nested or encapsulated networks, actors can be limited to a set of multi-lateral actors engaged in the utilization of complementary resources (Prenkert, 2017).

\subsection{A dynamic view of business models}

A dynamic approach to the BM accounts for the evolutionary characteristics of the BM, as well as adding a variety of notions to the concept such as BM innovation (Bolton and Hannon, 2016; Chesbrough, 2010; Foss and Saebi, 2018), BM learning (Teece, 2010), BM evolution (Demil and Lecocq, 2010), BM erosion (McGrath, 2010), BM lifecycle (Morris et al., 2005) and BMT (Aspara et al., 2013). A dynamic approach also considers the BM in relation to the network (Jocevski et al., 2020). Regardless of the various notions added, the core of the dynamic approach is that a firm needs a constant transformation of the BM to stay competitive (Teece, 2010), which is based on technological shifts (Tongur and Engwall, 2014) and changing market behavior.

$\mathrm{BM}$ innovation is concerned with novel ideas of performing business, whereas BMT changes an existing business. To illustrate the slight and subtle difference, Markides (2006, p. 20) defines BM innovation as "the discovery of a fundamentally different BM in an existing business," while Aspara et al. (2013, p. 460) address how BMT is characterized by "a change in the perceived logic of how value is created by the corporation [...] from one point of time to another." Thus, the latter indicates how incumbent businesses manage changes in BMs over time and the value that migrates between different units and initiatives.

Several studies have a focus on developing new market structures through BM innovation or open innovation (Chesbrough, 2010). Radically new BMs have been seen to have the potential to disrupt market structures, as these are based upon the connection between different actors and interrelate to both the production and consumption side of business (Matthyssens et al., 2006; Sabatier et al., 2012). For a mature market experiencing technological uncertainty, new entrants' BMs initially seem to align to the dominating logic of the market. However, at later stages, they can reshape established market foundations (Sabatier et al., 2012). Nevertheless, more integrative approaches, considering BMT aiming to both shape and stabilize existing market structures, do exist (Koryak et al., 2018; O'Reilly and Tushman, 2008). This balance considers the management of increasing productivity and incremental improvements in the existing business and the entrepreneurial, novel and often more longterm way of thinking.

\subsection{Business model transformation}

As incumbent actors have invested a lot in existing technology and infrastructure, a BMT strategy aiming at consolidating existing market structure typically coexists with disruptive strategies where a firm uses a more proactive strategy to actively reshape the market structure (Ottosson and Kindström, 2016).

Storbacka et al. (2013) argue that BMT takes place gradually instead of in radical leaps, as often is the case in BM innovation. Different mechanisms drive the incumbents' BMT. They mutate, often from an existing shape, as an effect of coevolutionary relationships between the firm and the market (Tikkanen et al., 2005). With its actors and roles, the market 
network is increasingly seen as key elements of the BM (Shafer et al., 2005), where generated wealth and revenues should be geared to the owner and a broader range of stakeholders as well. Still, the literature that examines the actors' roles surrounding the focal firm is weak (Palo and Tähtinen, 2013). Theoretically, a networked BM approach geared toward a broader range of actors is addressed by several scholars (Bankvall et al., 2017; Palo and Tähtinen, 2013).

BMs of incumbents often become outdated in markets characterized by rapid change and changing value landscapes (Hacklin et al., 2018). One might, hence, argue that the BM is always in a transformation process. However, there is always a significant short-term economic risk related to abandoning the existing BM. To stay competitive in the long run, organizations can instead consider dual structures (O'Reilly and Tushman, 2008). Still, balancing efficiency and innovation is a difficult management task. O'Reilly and Tushman (2008) suggest separating aligned organizational architectures (e.g. BMs), hence having the possibility to use the resources needed for explorative businesses without being overtaken by the mature businesses.

Overall, BMT can be seen as an evolutionary process over time, with both strategies aiming at disrupting and dissolving the existing industrial market structures through marketshaping activities, with activities aiming at stabilizing and incrementally developing the existing market structure. Firms need to balance the ambidexterity in the BMT processes. The core of the dilemma is the strategic intent of stabilizing the existing market structure while simultaneously shaping new market structures and practices in a favorable direction.

\section{Methodology}

The paper adopts an explorative, qualitative approach to provide theoretical and managerial insights on BMT mechanisms. We have performed a case study of a business network composed of five firms within the electric utility industry. Case studies are frequently used by scholars interested in business networks (Dubois and Gadde, 2002) to develop an in-depth understanding of the phenomenon (Eisenhardt, 1989) and to reveal the complex phenomena embedded in the contextual setting (Eisenhardt and Graebner, 2007). The chosen approach enabled us to capture contextual aspects and the empirical richness required. Theorizing from case data is presumed to generate accurate, interesting and testable ideas (Eisenhardt and Graebner, 2007), which is in line with this paper's aim.

Within the case, we have identified three illustrative examples of recent attempts to initiate BMT. These are used to substantiate our conceptual claims in this paper. The selection of the three illustrative attempts is based on unique access to a network of firms within the electric utility market (Table 1). These are hereafter named f-Energy, Trading, K-Energy, LEnergy and Development. The three illustrative examples discussed in this paper were purposely selected from a larger empirical investigation (Eisenhardt and Graebner, 2007). The selected examples were particularly interesting to investigate, as they illustrate both the shaping strategy and stabilizing strategy of BMT in a changing market context.

\subsection{Data collection and analysis}

Case studies often rely on multiple sources of support (Yin, 2003). The exploratory fieldwork was informed by key concepts discussed in previous research and a range of different data collection methods was used, to get a rich understanding from multiple perspectives. Many marketing researchers interested in networks tend to view different business phenomena as complex and multifaceted, with the ambition of capturing the contents of interactions and relationships in thick, rich descriptions (Dubois and Gadde, 2002). The fieldwork consisted of a mix of face-to-face interviews, observations (firm-internal meetings, round table discussions and workshops) and collection of secondary data, where the different data collected complemented each other and gave us a better understanding of both challenging mechanisms and defending mechanisms of BMT in a changing market context.

Managers from five cooperating firms were used as the interviewees (Table 2). In total, 25 interviews were performed between 2017 and 2020. The interviewees had qualified knowledge of the overall, strategic, market and operational parts of the businesses. An interview guide containing different themes, such as industry change, strategy, market trends, offerings, current BMs, transformation processes, strengths, weaknesses, opportunities and threats as perceived by the firms and ongoing collaboration projects, was prepared in advance. The interview guide has a clear anchoring in the literature discussed. The questions applied an open-ended question approach to ensure the interviewees could speak freely about each theme, depending on their positions. The interviews lasted between 30 and $100 \mathrm{~min}$. All interviews (except one) were recorded using a digital voice recorder and transcribed verbatim. Most interviews were performed with $\mathcal{f}$-Energy, as this is the firm in the network that has a more prominent role than the other firms in all three examples. During the majority of all interviews, two researchers were present.

A significant amount of time has been dedicated to observing and participating in firm-internal meetings and site visits ( $36 \mathrm{~h}$, during 2018), round table discussions (16 h, during 2016-2019) and workshops (16 h, during 2019). Detailed field notes were made during all meetings. When possible, recordings were also made. Participations during interviews gave the authors a better understanding of all actors in the network, which was very important when observing the interactions between the firms during different meetings. The interviews made it possible to ask questions regarding things that were discussed during meetings. The purpose of the collected secondary data was mainly to increase our understanding of contextual factors and changes in the surrounding ecosystem. We collected and studied documents such as strategic plans and reports provided by the firms, annual reports, press releases, press articles and industry reports. Hence, the secondary data included internal and official records of the focal firms. All secondary data has been collected in a document management system to ensure better structure and accessibility for the researchers involved.

The parts of the collected data with relevance to the present paper were coded and related to the analysis's various points. The analysis was guided by three different dimensions that is 
Table 1 Key actors in the network revolving around J-Energy

\begin{tabular}{|c|c|c|c|c|}
\hline & Main business & Size & Owner & Location \\
\hline $\begin{array}{l}\text { J-Energy } \\
\text { Founded in the late nineteenth century }\end{array}$ & $\begin{array}{l}\text { Production (of electricity } \\
\text { and district heating), grid } \\
\text { operations and electricity } \\
\text { retailing }\end{array}$ & $\begin{array}{l}300-500 \text { employees; } \\
\text { turnover of MEUR 500- } \\
1,000 ; 200,000-300,000 \\
\text { customers in grid and } \\
\text { retail (>1,000 GWh/year) }\end{array}$ & $\begin{array}{l}\text { A group of } \\
\text { municipalities }\end{array}$ & $\begin{array}{l}\text { Headquartered in mid- } \\
\text { Sweden, multiple regional } \\
\text { subsidiaries in southern } \\
\text { Sweden, including in } 0 \\
\text { county }\end{array}$ \\
\hline $\begin{array}{l}\text { Trading } \\
\text { Founded in the 1980s }\end{array}$ & $\begin{array}{l}\text { Electricity trading and } \\
\text { consultancy services }\end{array}$ & $\begin{array}{l}\text { 10-20 employees; } \\
\text { turnover of MEUR 100- } \\
250 \text { (trading) }\end{array}$ & J-energy & 0 county \\
\hline $\begin{array}{l}\text { K-Energy } \\
\text { Founded around the year } 1900\end{array}$ & $\begin{array}{l}\text { Production (district } \\
\text { heating, biogas and small- } \\
\text { scale hydro), grid } \\
\text { operations and electricity } \\
\text { retailing }\end{array}$ & $\begin{array}{l}\text { 150-250 employees; } \\
\text { turnover of MEUR 50-100 }\end{array}$ & Municipality K & 0 county \\
\hline $\begin{array}{l}\text { L-Energy } \\
\text { Founded in the } 1910 \text { s }\end{array}$ & $\begin{array}{l}\text { Production (of electricity } \\
\text { and district heating), grid } \\
\text { operations and electricity } \\
\text { retailing }\end{array}$ & $\begin{array}{l}\text { 25-50 employees; } \\
\text { turnover of MEUR 15-30; } \\
10,000-15,000 \text { customers } \\
\text { in grid and retail (around } \\
200-400 \text { GWh/year) }\end{array}$ & Municipality L & 0 county \\
\hline $\begin{array}{l}\text { Charging } \\
\text { Founded less than } 10 \text { years ago }\end{array}$ & $\begin{array}{l}\text { EV charging infrastructure } \\
\text { and end-user relationships }\end{array}$ & $\begin{array}{l}\text { 25-50 employees; } \\
\text { turnover of MEUR 5-10; } \\
20,000-50,000 \\
\text { subscribers ( } 50 \%-100 \% \\
\text { growth year-to-year); } \\
>1,500 \text { charging posts in } \\
\text { its public network }\end{array}$ & $\begin{array}{l}\text { J-energy and two } \\
\text { other regional } \\
\text { utilities }\end{array}$ & $\begin{array}{l}\text { Local presence through } \\
\text { partners all over Sweden, } \\
\text { headquarters in Southern } \\
\text { Sweden }\end{array}$ \\
\hline $\begin{array}{l}\text { Development } \\
\text { Founded in the early } 2000 \text { s }\end{array}$ & $\begin{array}{l}\text { Developing new ventures, } \\
\text { small-scale wind power }\end{array}$ & $\begin{array}{l}\text { 5-10 employees; turnover } \\
\text { of }<10 \text { MEUR }\end{array}$ & $\begin{array}{l}\text { A group of } \\
\text { municipalities }\end{array}$ & 0 county \\
\hline
\end{tabular}

Table 2 Interviews

\begin{tabular}{llllc}
\hline Firm & Position & No of interviews & Duration & Year \\
\hline J-energy & CEO & 1 & $60 \mathrm{~min}$ & 2019 \\
J-energy & Head of Partner Relations & 3 & $29 \mathrm{~min}, 21 \mathrm{~min}, 60 \mathrm{~min}$ & $2017,2019,2019$ \\
J-energy & Head of New Businesses & 3 & $102 \mathrm{~min}, 20 \mathrm{~min}, 26 \mathrm{~min}$ & $2018,2020,2020$ \\
J-energy & R\&D Manager & 2 & $78 \mathrm{~min}, 20 \mathrm{~min}$ & 2018,2020 \\
J-energy & Head of Power Grids & 1 & $90 \mathrm{~min}$ & 2018 \\
J-energy & Head of Consumer Relations & 2 & $70 \mathrm{~min}, 51 \mathrm{~min}$ & 2018,2018 \\
J-energy & Head of Sales & 1 & $81 \mathrm{~min}$ & 2018 \\
J-energy & Head of Public Relations & 1 & $62 \mathrm{~min}$ & 2018 \\
Trading & CEO & 1 & $75 \mathrm{~min}$ & 2018 \\
K-energy & CEO & 1 & $46 \mathrm{~min}$ & 2018 \\
K-energy & Marketing Manager & 1 & $51 \mathrm{~min}$ & 2018 \\
K-energy & Deputy CEO & 1 & $33 \mathrm{~min}$ & 2017 \\
L-energy & CEO & 3 & $54 \mathrm{~min}, 28 \mathrm{~min}, 21 \mathrm{~min}$ \\
L-energy & Marketing Manager & 1 & $50 \mathrm{~min}$ & $2017-2019$ \\
L-energy & Communication Manager & 1 & $20 \mathrm{~min}$ & 2018 \\
Development & CEO & 2 & $26 \mathrm{~min}, 67 \mathrm{~min}$ & 2020 \\
\hline
\end{tabular}

technology, customer and offering. These dimensions were particularly interesting to investigate in the changing market context. The dimensions were linked to the different strategies, categorized as either shaping or stabilizing. The transcribed interviews and field notes from observations that could be sorted into one of the three dimensions were copied into one document. Initially, each author conducted this step individually; this was followed by several meetings to discuss potential findings. Findings were then synthesized in the light of previous research to ensure the theoretical contribution of this paper and to narrow down the findings. Thus, the development of the framework (Figure 1) was largely empirically driven. The results of this analysis are presented in the upcoming section. 
Figure 1 The BMT model

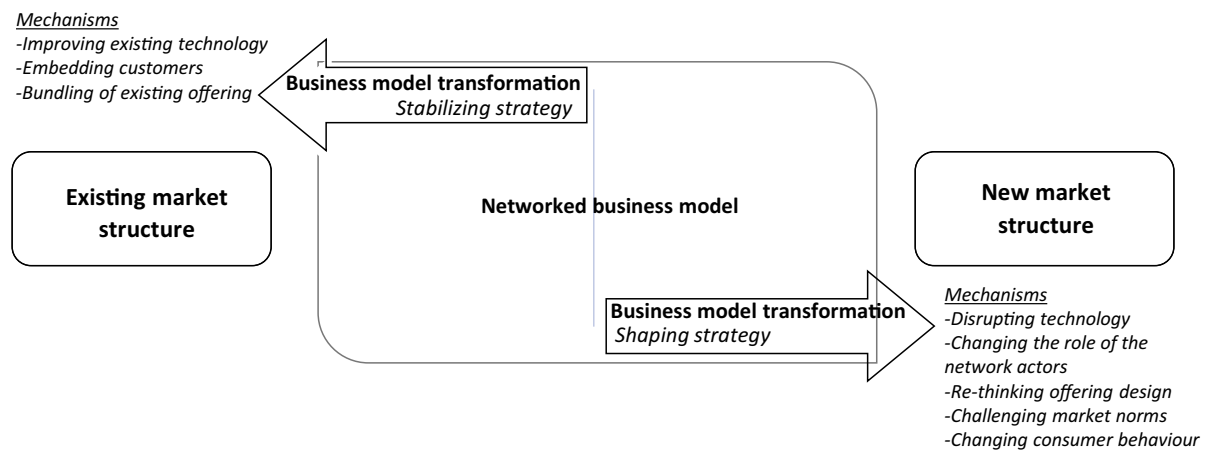

\section{Business model transformation in the electric utility industry}

Looking at a market that is undergoing dramatic changes, the 2020s are expected to be the most disruptive period in the history of electric utilities (PA Consulting, 2016; PwC Reports, 2016; Sioshansi, 2014). The conventional BMs are based on large-scale distant generation (e.g. nuclear power and hydropower) and grids that distribute electricity great distances to serve ratepayers attached to meters. However, with a set of recent and approaching innovations, the dominant modus operandi, in the near-term, is challenged by a more decentralized, networked, self-supporting way to operate. This impending shift toward a multifaceted market is expected to overturn the electric utilities' traditional roles and drive them to transform their positions and BMs (Brown et al., 2015). The anticipated challenge is made possible from megatrends, including distributed electric generation, smart microgrids and new energy storage methods (Overholm, 2015; Saba, 2014). Transformations can be seen along three main dimensions technology, customer and offering - and represent the BM's central dimension.

The rest of this section covers three different but recent endeavors by incumbent utilities to create new value propositions while at the same time not to lose or throw away what they already have. These three are hosted in a business-tobusiness network revolving around a middle-sized utility (here referred to as $\mathcal{f}$-Energy) that has a subsidiary (Trading) and smaller partners (e.g. K-Energy, L-Energy and Development) (Table 1).

\subsection{The charging network}

Still today, electricity subscriptions are linked to a particular residence rather than a person or a family. Families who own multiple residences need multiple subscriptions. This has long been the case but may change as part of the disruption. To date, with the introduction of electric vehicles (EVs), the need for considerable electricity consumption away from home increases.

In response, several competing players, in Sweden and in many other countries, are building public charging network (CN) stations, such as at rest areas along highways, at gas stations, at supermarkets, at car dealerships and at restaurants. Typically, CN stations are either owned by a car manufacturer (e.g. Tesla), an electric utility, independents (e.g. a supermarket that offers free charging to customers) or are co-owned. While car manufacturers typically exclude other brands of cars from its $\mathrm{CN}$, public CN stations owned or co-owned, by electric utilities are typically open for everyone who is ready to pay for electricity. To this end, a set of local and regional electric utility firms in Sweden cooperate in national CN stations - in this paper referred to as Charging (Table 1 and Figure 1). While a joint venture by three regional utilities, where $\mathcal{F}$-Energy is one of the founding owners, the network includes a large set of smaller, local partnering utilities (and restaurants, supermarkets, etc.) that together form the largest public $\mathrm{CN}$ in Sweden, offering charging facilities throughout the country. In other words, by cooperating and pooling local resources for national coverage, Charging's value proposition to EV drivers is convenient charging all over Sweden with a single access card. K-Energy's marketing manager laid out his thoughts:

[Pooling local resources] is increasingly important. Because we cannot solve everything in $\mathrm{K}$. But our customers want a simple and complete service to buy. So, to be able to solve the customer's future needs, you have to be more flexible to collaborate in building your own offerings [...] Charging takes care of the customer interface with payment system and such [...] It has something similar to a fuel card that you use to recharge the car at charging stations.

Besides selling and installing charging posts to firms and homes, Charging is building a nation-wide public network at strategic positions (e.g. restaurants, shopping malls and railway stations). However, charging itself does not own the charging stations after selling and helping out with the installation; the many local partners that also take title to the electricity from that charging station do. For local electric utilities, being part of the $\mathrm{CN}$ is an opportunity to compete on equal ground with the largest competitors with their own nation-wide networks. By building, owning and caring for a local subset of charging posts in the municipalities of $\mathrm{L}$ and $\mathrm{K}$ (23,000 and 30,000 inhabitants, respectively), local utilities L-Energy and K-Energy are typical partners of the CN. L-Energy and K-Energy might compete in the electricity retail market but work closely together in other aspects. Their regional character and smallness, each owning a distribution grid that covers less than $1 \%$ of Sweden's area, makes it impossible for them to offer nation-wide charging facilities on their own. So, while each charging pole is owned and maintained locally, they are also cobranded with charging and part of the larger network. Despite doing some traditional marketing and cooperating with a car leasing provider, charging reaches new customers through the already established customer relationships of each such local 
firm part of the network, such as L-Energy and K-Energy. When an $\mathrm{EV}$ owner charges at a station owned by, for instance, $K$ Energy, that customer pays Charging (based on his/her subscription plan with charging), while charging, in turn, pays K-Energy for the electricity, keeping a small fee for marketing, administration and other services. The marketing manager at K-Energy explained:

The electricity that we sell for that charge, it goes through our distribution grid, and it is our electricity retailing [that has title to the electricity], but it is Charging who invoices [the customer] and then sends it [the money] back [...] and, when it comes to [selling and installing] new charging posts [...] we have a retailing agreement with them [Charging].

Upon charging, the EV driver who needs a refill uses a special card to access the charging post and for the firm to track the consumption. While not actually owning the infrastructure, the co-owned charging handles end-user relations, several different subscription plans and invoicing. Hence, customers of, for instance, K-Energy, that drive an EV and charge through the $C N$ get (at least [1]) two separate electricity bills - one for the household electricity (from K-Energy) and one for the EV charging away from home (from charging). Still, the electricity subscription with an identification card, which enables charging an EV anywhere in the country, as well as in partners' networks in other countries, opens a possible future where electricity subscription is not limited to one particular building but rather linked to a person who has a consumption plan (similar to a cell phone plan) that allows access to electricity wherever and whenever the person needs it. The interviewees outlined future ideas to integrate the bills to include also charging away from home. However, for the time being, customers have dual relationships, which to date favors the promotion of charging more than charging helps bring in new customers to the local utilities. The aforementioned marketing manager described:

It is not a dealbreaker. For us right now, it is primarily about helping the city move into the future [of clean energy] by getting the right infrastructure in place. [At least] we get the electricity retail deal on the charging pole, but besides that, we are mostly a middleman [in the supply chain]. And, so, we got some kind of co-brand: like a sticker on the post saying, 'Powered by KEnergy'.

Shaping strategies, in this case, relate to building new technology and infrastructure to form new sustainable alternates for the existing fossil-fueled market. In the new market structure, the collaboration pattern between electric utilities is changed: the interactions between them are deeper and the whole idea of the $\mathrm{CN}$ is built on a nationally trustful network. Besides collaboration, network orchestration is an essential shaping strategy mechanism, where the focal firm influences the network roles. Finding new ways of interacting and building alliances provides a basis for market disruption and paves the way for new market configurations.

Moreover, the illustration of Charging indicates a shaping strategy toward a platform-based business where focus shifts from the single firm's creation of value toward the valuecreating network and more specifically on resource integration and value-in-use for the customer. The shaping strategy is not limited to the firm's boundaries; instead, it is the network that the firm is situated within that defines the boundary.

Stabilizing strategies, in this case, relate to the firm's ambition to keep the local energy customers by providing something that can offer a nation-wide solution within a local market offer, and hence, make use of local resources by combining such resources in a network of local utilities. This strategy reuses the old structure of the existing market (the transmission and distribution grids) and only strives for incremental improvement. Another stabilizing strategy is illustrated by the re-bundling of existing market offerings instead of completely new ones. Coming from a history of selling a commodity (Storbacka et al., 2013), the provider now integrates more services in addition to the basic commodity. As it is not a matter of a new offering typology but an extension of an already market-accepted offering, it can be seen as a natural and modest way of developing the existing market logic without very radical, as it still is based on the same fundamental premises as the long-existing business.

\subsection{The surplus storage}

Traditionally, electricity consumers are characterized by passivity; electricity is produced in power plants and transmitted over the grid to a household attached to a meter that tracks consumption. A traditional customer rarely has any contact with the electricity firm other than via the invoice. This is, however, starting to change. Recently, residential solar cell prices have been dropping and growing numbers of Swedish households and firms have, spurred by authorities and subsidies, become "prosumers," meaning an actor that both produces and consumes electricity. The more solar cell panels produced, the lower the price of production; "Swanson's law" (Carr, 2012) states, that with every doubling of solar cell deployment, there has been a $20 \%$ reduction in cost since the 1970s. Hence, the home fabrication of solar electricity is seemingly becoming a better business every year. Nevertheless, to handle the time asymmetry between when the electricity is generated and consumed, it must be accompanied by a large and still rather expensive battery and/or access to the main power grid.

From the electric utilities and grid owners' point of view, the growing number of "prosumers" might have a large impact on their core BM because if a large bunch of customers only request grid access to cope with peaks in consumption and production dips, the grid owner still had to uphold the same grid capacity and high maintenance costs as today for just the peak hours, but will not be able to transmit as large sums of electricity in total over the year. This threatens the grid owners' fixed traditional per-kilowatt-hour price model.

Being an owner of hydropower plants and an electricity supplier to more than 150,000 households, $\mathcal{F}$-Energy (Table 1) recently launched an attempt to answer this challenge. It offers property owners help to install solar cells and sets up deals so that customers can swap all that they overproduce in the summer (when there are many hours of sunshine and little need for heating of houses) for kilowatt-hours out of the main grid in return whenever they need them in the winter months (when it is dark and requires much warming). For f-Energy, every kilowatt-hour its customers' solar cells deliver to the common power grid during the summer month means one less they have to produce in their hydropower plants. That means, in turn, higher levels in their water reservoirs and more potential energy stored until the winter for production. In other words, the water-sharing solution offered stores the prosumers' production for later use just like a battery can do, but instead of 
each household investing in its own battery (with all its limitations and costs), $\mathcal{f}$-Energy makes use of its large infrastructures (water reservoirs) that they already have invested millions into; no batteries of limited capacity at homes are needed. In other words, this case shows that in this way, an incumbent ( $\mathcal{f}$-Energy) has found a new use (storage) of an old resource (water reservoirs) to deliver value (answering seasonbased supply-demand asymmetry) to a growing customer segment (prosumers). The Head of New Businesses at $\mathcal{f}$-Energy discussed the rationales to why it launched the new service:

[Customers] might be more attracted to the sharing economy, and with the products we have today, we are starting to move [our BM] in that direction [...] The value for the customer is that electricity prices [in Sweden] are generally low in the summer. So that's partly about not having to sell electricity cheaply in the summer and buy it expensively in the winter, without being able to [as with storage] profit from that value difference. Then there is the nice feeling of being able to use one's own production to a greater extent.

In providing this service, the prosumer's local grid owner must also be involved. Thus, in comparison to a local storage solution with batteries close to the production site, the prosumer cannot go off-grid but must stay connected to the main transmission grid, as well as that the customer with this service needs to buy and sell electricity through a retail contract with $\mathcal{f}$-Energy, which helps raise higher exit barriers.

Surplus storage (SP) is a complimentary service that must be combined with a two-way subscription with $\mathcal{F}$-Energy. Thus, to reach beyond the few prosumers currently in contract with $\mathcal{f}$ Energy, others must either first turn prosumers or be recruited from competing utilities. Currently, $\mathcal{f}$-Energy customers are reached through its own channels, while other potential clients are harder to reach, but $\mathcal{f}$-Energy works with a set of direct and indirect channels to create awareness. For those households that turn prosumers by investing in a rooftop solar package from $\mathcal{f}$-Energy, the firm runs campaigns where the SP deal is included.

While offering this service partly as a way to build stronger ties and add value to prosumers that chose $\mathcal{f}$-Energy for their electricity subscription plan, the offering itself is not profitable on its own merits. Receiving kilowatt-hours "for free" in the summer when marginal prices normally are relatively low under the condition of returning them in the winter when marginal prices often are higher does not, analyzed in isolation from the total $\mathrm{BM}$, add positively to the revenues. However, $\mathcal{f}$-Energy adds a subscription to the service, covering their cost to hedge the prices and avoid losses from the offering. Reflections from the Head of New Businesses at $\mathcal{f}$-Energy:

It started primarily as a PR thing. We didn't even think it would be as big as it turned out. We have actually won a lot of new customers from it, and it has added a positive image to the brand within this special target group. Previously, we were allowed to offer net charge [meaning you charged prosumers only for the net between consumption and production], but it became forbidden for tax reasons. So, this was an attempt to get as close to net charge as possible, but on the right side of the regulations.

Overall, if the offering helps attract new prosumers or gets current prosumers to shift to $\mathcal{f}$-Energy for their subscription plan or if it keeps prosumer attached to their distribution grid to share the costs for grid maintenance, then $\mathcal{F}$-Energy's BM can benefit. Moreover, this service can also act as an exit barrier. When the old-fashioned subscription plan is all about low cost, and there is almost nothing that holds the customer, prosumers that also have a grid-connect storage plan like this cannot as easily change to another supplier. The Head of Customer Relations at $\mathcal{F}$-Energy explained that, so far, it mostly sells the storage service to those that already have installed rooftop solar or as an add-on service to new customers:

When we sell the solar panels, the rooftop hardware, we offer the storage service for free the first year to sell a package and [. . . ] build relationships.

Shaping strategies, in this case, are related to the fostering of new customer behavior (the prosumer that simultaneously is both producer and consumer). Previously, the customer has been a passive consumer; meanwhile, $\mathcal{F}$-Energy both changes and challenges the existing value offering in the market (related to instant consumed electricity). Instead, the consumer can now store energy in large reservoirs as long as they are connected to the grid. $\mathcal{F}$-Energy showed how the transformation toward a dynamic and iterative BM had taken place: replacing the passive receiving customer with an active prosumer. The prosumer's entrance in the BM of $\mathcal{f}$-Energy forces the BM to become more dynamic, as it is not only a matter of describing the firm's business but also a formula for continually supporting the customer in a collaborative manner.

Stabilizing strategy can also be seen here, as it is the existing infrastructure that enables the new business idea. Therefore, incremental improvements need to be made in existing technology (grid upgrades). Furthermore, no new infrastructural investments need to be made by the firm, as the large reservoirs already exist; instead, it is about a new offering bundling and fostering a new mindset of the customer.

\subsection{The solar farm}

The third example of BMT covers network aspects. A BMT initiated from the incumbent electric utility firm offers consumers who lack possibilities to have a photovoltaic system (PVS) on their own building an alternate: shares in a cooperatively owned solar farm (SF). The incumbent utility can in this BMT use its accumulated expertize in energy production and power plant maintenance, while the consumers receive the equivalent of their own solar cells.

Moreover, to build large-scale PVS outside of the cities on flat ground and adjusted to maximize the insolation from the sun is more cost-efficient than small residential PVS on top of already existing buildings. For consumers who rent a flat and consumers who need very little electricity, smaller shares in a cooperatively owned SF can still be profitable as many shareholders split the fixed cost of installation work.

Both L-Energy and $\mathcal{f}$-Energy have each recently built an SF in which consumers can buy shares to generate "their own" electricity cooperatively. First, $\mathcal{F}$-Energy partnered with a local real estate firm that bought $50 \%$ of the farm shares to support apartment tenants with locally produced, clean electricity, while the other $50 \%$ was intended directly for the consumer market. As the Head of Partner Relations at $\mathcal{f}$-Energy recalled:

[The value proposition of the SF shares] addresses those who cannot, do not want, do not have the finances to install a facility on their own roof, or do not have the right kind of roof. Then you can still own solar power, but in a simpler way and to a smaller initial investment [...] What we want to deliver is a positive vibe of belonging to something, a movement, a feeling of being a self-producer without having to put it on the roof; that you participate in real production.

The offer to buy these shares, at about EUR 83 (SEK 850) each for $100 \mathrm{~W}$, was first announced in $\mathcal{F}$-Energy's own 
communication channels to reach existing customers. The Head of New Businesses at $\mathcal{f}$-Energy stated:

To raise awareness, it was primarily communicated via our customer newsletter to current customers and through our website. I think $90 \%$ [of those that bought it] are local residents in the region, and probably 8 or 9 out of 10 were already grid or retailing customers.

The L-Energy setup is slightly different. The customers do not own the solar cell in that case but rent $300 \mathrm{~W}$ panels for about EUR 67 (SEK 680) each for three years. Once a customer has signed up for a rental agreement, it becomes an exit barrier, meaning that a consumer that controls shares in the L-Energy park can also use L-Energy as its electricity retailer for as long as the rental lasts. In practice, a shareholder pays for its total consumption, but L-Energy reduces the bill by the value the renter's panels have produced. The communication manager at L-Energy introduced its new offer as below:

We have chosen not to offer a cooperatively owned SF. Instead, we offer solar power subscriptions: it means that you can rent a small section of the SF [...] and you get a refund every month that represents the weighted market value produced by your panels.

When asked about how the consumer price of the rental agreement compares to per-kWh deals, the interviewees at $\mathcal{f}$ Energy and L-Energy wanted to get around a head-to-head price comparison by introducing other values. The aforementioned communication manager at L-Energy stated:

There is, of course, a calculation. But you will never go break even if you only care about costs. So, we highlight other values. What we really are pushing for is that you make a good effort for sustainable production if you choose locally produced solar; that clean, carbon-free energy from the sun is for everyone to enjoy. Not only those who can afford to install it on their own roof. This is also for apartment owners to participate in.

As solar power is prioritized when Sweden is transforming to net-zero carbon emissions, both these SFs received around $20 \%$ installation cost subsidies (based on installed $\mathrm{kWs}$ ) from the state, about the same subsidies as rooftop PV systems get. However, while rooftop installations only pay tax and grid transmission fees for the net trading of $\mathrm{kWhs}$, consumers that own production away from where they consume must pay tax and transmission costs for every $\mathrm{kWh}$; they then get a deduction on the bill for the value of what is produced by its share in an $\mathrm{SF}$. In other words, while the installation cost per $\mathrm{kW}$ in a largescale SF is substantially cheaper than on a rooftop, the overall cost comparison is also dependent on the current tax legislation, which might change. The Head of Partner Relations at $\mathcal{f}$-Energy discussed the uncertain calculations of payback time:

At a customer's first glance, it does not look good, but it can be very different over the coming years. We don't know about regulations and policies. To date, for comparison, you avoid some costs if you put it on your own roof instead, such as network fees and taxes.

Currently, the SFs of $\mathcal{f}$-Energy and L-Energy are more experimental and promotional ventures to try out the potential and show that they want to be frontrunners in the green transformation. Both firms can accept if the SF is not yet cash cows. From the firms' horizon, experience, environmental benefits and the ability to lock in retail customers in long-lasting relations are currently the most important reasons to build and maintain cooperatively owned SFs, not the least to show direction intra-organizationally to personnel and stakeholders, as addressed by the Head of New Businesses at $\mathcal{F}$-Energy:
We worked with "ambassadorship." So, everyone employed at J-Energy was involved in building the park as a one-day event. It was to get everyone to know the fundamentals of how it works, and it generated quite a lot of attention in social media from what all of us [the employees] shared. You need to know that solar power is still the "new" technology internally. It is still more profitable [in the short term] to build wind power. But in this case, we built it on the premise that there was a high-interest thing to do: an opportunity to showcase us and the technology.

However, for electric utilities, if (or when) consumercooperative SFs become big business, electric utilities might transform their BM to become more like real estate firms that build, manage and deliver services to their shareholders instead of owning the means of production. In that way, it would be a "game-changer" for their BMs if the utility project and deploy production means, but not lock in millions of dollars for the entire life of the facility. Moreover, instead of per kWh deals, ownership and tenancy arrangements transfer the risks related to, for instance, loss of production (such as lack of sunshine). The Head of Partner Relations at $\mathcal{f}$-Energy explained:

The risk for the customer is, like this year [2020], with extremely low electricity prices in the summer, if the price calculation breaks, it's the shareholder, not us, who bears the risk. Also, of course, if the solar farm produces less than calculated.

The SF example also illustrates shaping strategies in terms of changing the relationship between the firm and the customerfrom the customer as the passive receiver of electricity to a partner who owns the means of production. In terms of technology, the large-scale PVS indicates a technology leap, moving away from traditional electricity sources such as hydropower and biopower plants.

Stabilizing strategies can be seen, as the electricity provider still wants to be central in the existing market structure: to be "the spider in the grid," as this provides possibilities to sell addon services, such as maintenance services. Meanwhile, keeping the focal market position is necessary to protect the grid operation business and the already-existing customer relationships as it adds high exit barriers that keep the customer in the relationship. Incremental improvements of an existing technology, already accepted in the market, is a BMT that builds on the shared understanding of what the market is and how it should be treated. Through maximizing material and energy efficiency, the BM is transformed without any radically new technology (Bocken et al., 2014). In the electric utility sector, firms fine-tune their already-existing technology (for example, improve capacity in the electricity distribution network). This is also done to secure the mature business in the electricity utility firms.

\subsection{Analyzing shaping and stabilizing strategy}

Based on our study, BMT can be seen as a process that contains both a proactive, strategic intent of shaping a new market structure and a defensive strategy of preserving an existing market structure. We have seen how both these strategies co-exist and benefit each other (Table 3 and Figure 1).

A more proactive BMT strategy is to challenge existing market logic with the potential to disrupt and dissolve the existing market structure and shape a radically new type of market practices and innovate the way value is perceived (Matthyssens, 2020). This strategy aims to change the dominating modus operandi of the market and involves several mechanisms: the development of radically new technology 


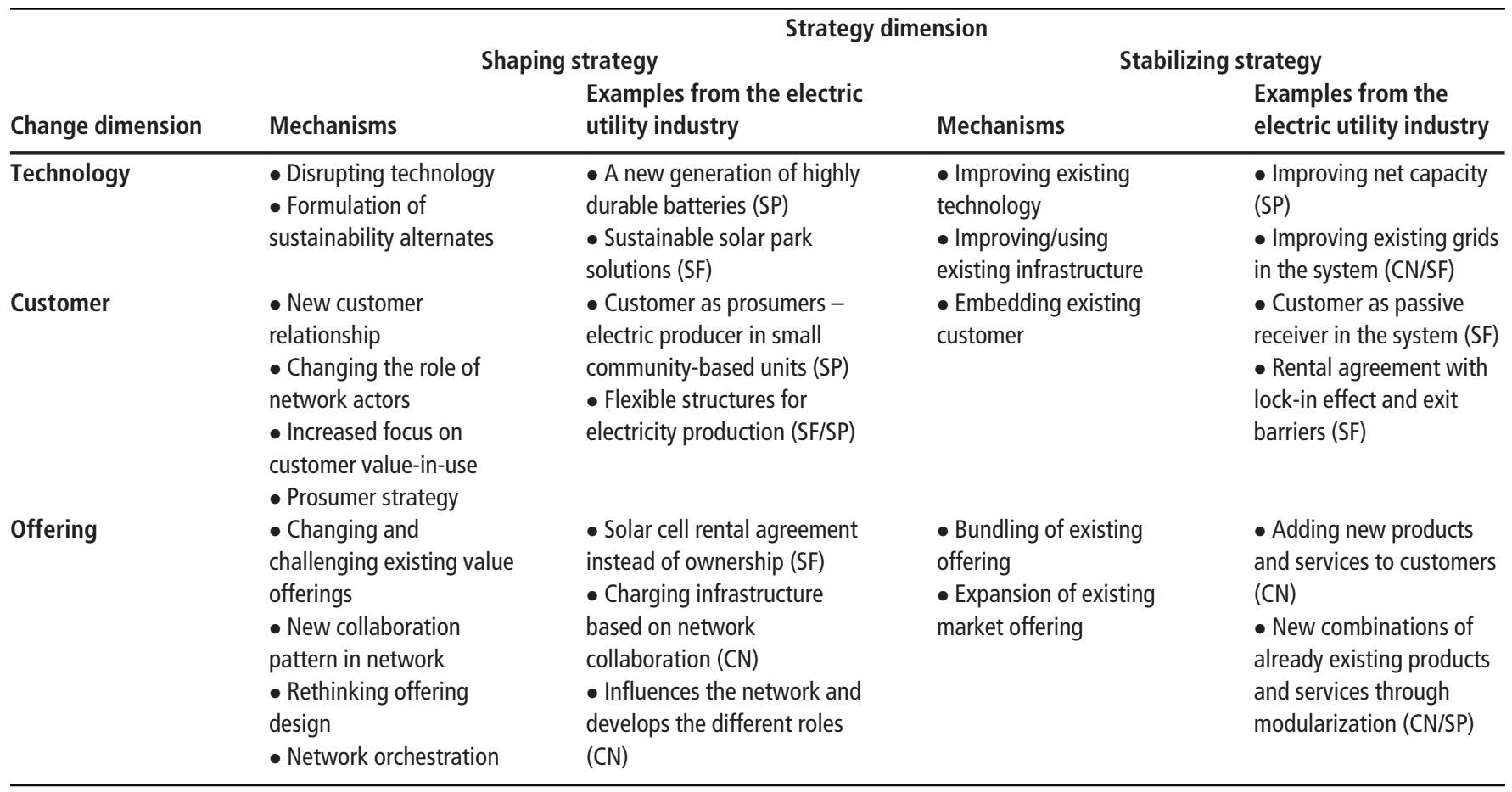

(Pateli and Giaglis, 2005), the creation of new philosophy and mindset (Ringberg et al., 2018), the development of new collaboration patterns in the network (Mustak, 2014) and the questioning of norms and the very foundation of the market in the form it is shaped today. The new market configuration in the electric utility market implies several advanced technical innovations (i.e. battery capacity), a shift from large-scale to small-scale revenue (i.e. a new mindset among the market actors), more flexible structures for electricity production (i.e. new collaboration patterns) and new ways of configuring value co-creation among the actors in the ecosystem (i.e. new norms and practices for the creation of value).

Stabilizing the existing market structure implies a stabilization and normalization of market activities (Teece, 2010) that is trying to keep the market's status quo with the given order of market practice among different actors in the network. This can be seen in the following mechanisms, namely, improving existing technology incrementally, embedding already-existing customers and integrating services in the existing market offering. These types of BMTs aim to keep the same level of revenues in the already-installed base of grid, machinery and customers. Another reason is to reach standardization that can reduce operational costs (improving existing technology), while a third goal is to integrate the value chain with more advanced service offerings and higher customer loyalty (integrating services).

\section{Discussion and conclusions}

We recognize a pattern of BMT containing two parallel strategies dealing with stabilizing existing market structures and shaping new market structures. This contrasts with the conventional BMT literature, mainly concerning how new markets are being shaped through radical innovation
(Chesbrough, 2010). Instead, it follows the analysis by Storbacka et al. (2013), suggesting a more gradual transformation process. By advancing research on BMT (Aspara et al., 2013), we have identified the mechanisms behind the strategies and discussed the balance between the parallel processes of stabilizing and shaping markets. The findings emphasize BMT as embedded in the network, and hence, part of an evolutionary pressure previously recognized by Tikkanen et al. (2005).

The BMT dilemma deals with the duality of stabilizing and shaping, and this study has identified two major strategies and described them and the involved mechanisms based on empirical insights. A balance between a shaping strategy of disintegrating existing market structure and a stabilizing strategy of consolidating existing market structure incrementally through BMT is pivotal for incumbents. By acknowledging the dual aspect of BMT, the firm can allocate resources for both to co-exist (Figure 1).

However, to date, many previous conceptualizations of innovation and transformation of extant BMs given in the current body of literature do not seemingly obey the need of incumbent network actors of balancing strategies for stabilizing (i.e. gradual and incremental transformation) and shaping (i.e. more radical change). Thus, we can argue that the inconsistency in addressing these two together in an integrative framework and how to balance them results in a lack of theoretical coherence and managerial relevance in the resultant conceptualizations of the BMT process. Hence, our suggested framework fills this scholarly void. We acknowledge, despite this, that the novel framework does share some key features with other change-focused streams within the wider management literature, for example, dynamic capabilities (Cabanelas et al., 2013; 2018; Eltantawy, 2016; Wang and 
Hsu, 2018) and narrated concepts such as innovation capabilities (Cheng and Chen, 2013; Santos-Vijande et al., 2013) and market-shaping capabilities (Windahl et al., 2020).

We argue that above mentioned approaches - with a focus on skills, procedures and tacit dispositions - only to a limited degree can explain how the BM is being varied. While dynamic/ innovation capabilities can represent an approach, which includes adapting and re-bundling resources and competencies within the focal organization to match changes in its environment, our addressed approach is mostly focused on the process and outcome at the network level. This includes implications of change for all the different features of a BM. While the dynamic/innovation capabilities to initiate, create and support BMT, of course, can be critical human assets within a firm (along with, for example, physical, intellectual and financial resources), these dispositions are not per se the focal object of study in our framework. Rather, we see market-shaping capabilities (Windahl et al., 2020), as well as strategic capabilities (Huikkola and Kohtamäki, 2017), in the role of enablers and constrainers for innovation and change, as potential complements that could give our integrative framework further detail and as a promising avenue to more strongly bridge the gap between overlapping theoretical traditions.

\subsection{Theoretical and practical contributions}

By considering BMT as a process with dual strategies we contribute to the research by empirically identifying strategies for this dual-directional process aiming to overcome the BMT dilemma. While most prior BMT studies have focused on the challenges of developing new business units as a response to a changing market landscape, not enough attention has been paid to the balancing and interrelated process of both disruption and stabilization in a business network. This study advances knowledge about strategies involved in the BMT processes, while proposing an integrative approach for BMT, hence balancing between market shaping and market stabilization. This contributes to the discussion of Murmann and Frenken (2006), where the emergence of a dominant design at a higher system level is affecting development strategies at a lower system level, where more focus can be geared toward incremental improvements of existing business than searching for new ones. It also contributes to the emerging discussion on the interconnected and networked BM literature (Jocevski et al., 2020) by exploring empirical cases.

For practical relevance, this research has some important managerial implications that can support managers in incumbent firms, facing situations of a swiftly changing environment. The need to allocate resources for initiatives with potential return in the long term cannot be ignored (shaping strategy); instead, these are important for market success but need to be balanced with investments in the short term (stabilizing strategy), exploiting existing market opportunities. Further, as BMT takes place in networks of actors - large ecosystem or encapsulated business network (Prenkert, 2017) strategies for BMT typically need the actor's continuous involvement to succeed with both shaping and stabilizing strategies. Therefore, firms need to evaluate what type of strategies are used in different relationships and networks. By a better understanding of their interplay between shaping and stabilizing strategies, firms can overcome the BMT dilemma focusing too much on either strand of the BMT.

For incumbents transforming the BM, the firm's activities can be separated and categorized in accordance with strategic intent: activities aiming at disturbing the market structures or activities aiming at stabilizing the existing structure. By acknowledging the different nature of the activities, firms can overlook how they, in parallel, both shape and stabilize markets. If the magnitudes and direction of the activities create too much tension in the organizations, the firm is obliged to evaluate the strategies and re-thinking the transformation of the $\mathrm{BM}$. In this sense, the BMT is a part of the firm's strategic design (Windahl et al., 2020) for market shaping.

Finally, one of the most powerful strategies to disrupt a market structure is to combine new technology with changing the mindset or philosophy of doing business (Ringberg et al., 2018). Tongur and Engwall (2014) exemplify this with the electric road system and how such a technological shift will challenge truck manufacturers. In the current study, the tendencies toward a radical shift in technology and mindset exist in terms of radically new BMs, but these types of disruptions are rare and require entrepreneurial capabilities among management teams (Ringberg et al., 2018). Hence, developing the required capabilities to manage the different types of transformation is one important managerial implication.

\subsection{Future research avenues}

The need to consider BMT as a dual-directional process is emphasized in this study (Figure 1). By revealing strategies for shaping new market structures and stabilizing existing ones, the present study contributes to how firms overcome the BMT dilemma.

In the three empirical illustrations discussed, collaborations between different types of actors are important for transforming BMs. However, in many cases, BMs are considered a belonging of the firm (Mason and Spring, 2011), and literature that examines the roles of the actors surrounding the focal firm is still weak (Palo and Tähtinen, 2013). Thus, more empirical research on how networked BMs in different contexts are shaping markets is needed. Today, too much research solely focuses on firm strategies, and hence, forgot the crucial importance of the surrounding network (Klimanov and Tretyak, 2019) - both the business network with its business actors but also the larger ecosystem of actors from a variety of sectors (Jocevski et al., 2020). The key issue for firms involved in networked BMs is how to interact and collaborate. Scholars are encouraged to develop the field of BMT across different sectors to build advanced knowledge of how they relate to strategies of market shaping and market stabilization in different settings. Finally, as indicated above, we see also, within the larger strategy conversation, a need to further bring in and discuss the underlying capacities that enable (or perhaps, hinder) incumbents to move from one $\mathrm{BM}$ to another, where the innovation and market-shaping capabilities (Teece, 2018; Windahl et al., 2020) could be good candidates for discussion.

\section{Note}

1 In Sweden, households can buy electricity from a different retailer than the firm owning the local grid. In such cases, it is two separate bills. 


\section{References}

Aspara, J., Lamberg, J.A., Laukia, A. and Tikkanen, H. (2013), "Corporate business model transformation and interorganizational cognition: the case of Nokia", Long Range Planning, Vol. 46 No. 6, pp. 459-474.

Bankvall, L., Dubois, A. and Lind, F. (2017), "Conceptualizing business models in industrial networks", Industrial Marketing Management, Vol. 60, pp. 196-203.

Bidmon, C.M. and Knab, S.F. (2018), "The three roles of business models in societal transitions: new linkages between business model and transition research", Fournal of Cleaner Production, Vol. 178, pp. 903-916.

Bocken, N., Short, S.W., Rana, P. and Evans, S. (2014), "A literature and practice review to develop sustainable business model archetypes", fournal of Cleaner Production, Vol. 65, pp. 42-56.

Bohnsack, R., Pinkse, J. and Kolk, A. (2014), "Business models for sustainable technologies: exploring business model evolution in the case of electric vehicles", Research Policy, Vol. 43 No. 2, pp. 284-300.

Bolton, R. and Hannon, M. (2016), "Governing sustainability transitions through business model innovation: towards a systems understanding", Research Policy, Vol. 45 No. 9, pp. 1731-1742.

Cabanelas, P., Omil, J.C. and Vázquez, X.H. (2013), “A methodology for the construction of dynamic capabilities in industrial networks: the role of border agents", Industrial Marketing Management, Vol. 42 No. 6, pp. 992-1003.

Carr, G. (2012), "Sunny uplands: alternative energy will no longer be alternative", The Economist, Nov 21st 2012.

Cheng, C.C. and Chen, J.S. (2013), "Breakthrough innovation: the roles of dynamic innovation capabilities and open innovation activities", Fournal of Business $\mathcal{E}$ Industrial Marketing, Vol. 28 No. 5, pp. 444-454.

Chesbrough, H. (2010), "Business model innovation: opportunities and barriers", Long Range Planning, Vol. 43 Nos 2/3, pp. 354-363.

Demil, B. and Lecocq, X. (2010), "Business model evolution: in search of dynamic consistency", Long Range Planning, Vol. 43 Nos 2/3, pp. 227-246.

Dubois, A. and Gadde, L.E. (2002), "Systematic combining: an abductive approach to case research", fournal of Business Research, Vol. 55 No. 7, pp. 553-560.

Eisenhardt, K.M. (1989), "Building theories from case study research", Academy of Management Review, Vol. 14 No. 4, pp. 532-550.

Eisenhardt, K.M. and Graebner, M.E. (2007), "Theory building from cases: opportunities and challenges", Academy of Management fournal, Vol. 50 No. 1, pp. 25-32.

Eltantawy, R.A. (2016), "The role of supply management resilience in attaining ambidexterity: a dynamic capabilities approach”, Fournal of Business $\mathcal{E}$ Industrial Marketing, Vol. 31 No. 1, pp. 124-134.

Foss, N.J. and Saebi, T. (2018), "Business models and business model innovation: between wicked and paradigmatic problems", Long Range Planning, Vol. 51 No. 1, pp. 9-21.

Hacklin, F., Björkdahl, J. and Wallin, M.W. (2018), "Strategies for business model innovation: how firms reel in migrating value", Long Range Planning, Vol. 51 No. 1, pp. 82-110.

Huikkola, T. and Kohtamäki, M. (2017), "Solution providers' strategic capabilities”, fournal of Business \& Industrial Marketing, Vol. 32 No. 5, pp. 752-770.

Jocevski, M., Arvidsson, N. and Ghezzi, A. (2020), "Interconnected business models: present debates and future agenda", fournal of Business \& Industrial Marketing, Vol. 35 No. 6, pp. 1051-1067.

Kjellberg, H., Azimont, F. and Reid, E. (2015), "Market innovation processes: balancing stability and change", Industrial Marketing Management, Vol. 44, pp. 4-12.

Klimanov, D. and Tretyak, O. (2019), "Linking business model research and marketing: new network-based approach to business model analysis", Fournal of Business E Industrial Marketing, Vol. 24 No. 1, pp. 117-136.

Koryak, O., Lockett, A., Hayton, J., Nicolaou, N. and Mole, K. (2018), "Disentangling the antecedents of ambidexterity: exploration and exploitation", Research Policy, Vol. 47 No. 2, pp. 413-427.

McGrath, R.G. (2010), "Business models: a discovery driven approach", Long Range Planning, Vol. 43 Nos 2/3, pp. 247-261.

Mason, K. and Spring, M. (2011), "The sites and practices of business models”, Industrial Marketing Management, Vol. 40 No. 6, pp. 1032-1041.

Matthyssens, P. (2019), "Reconceptualizing value innovation for industry 4.0 and the industrial internet of things", fournal of Business \& Industrial Marketing, Vol. 34 No. 6, pp. 1203-1209.

Matthyssens, P., Vandenbempt, K. and Berghman, L. (2006), "Value innovation in business markets: breaking the industry recipe", Industrial Marketing Management, Vol. 35 No. 6, pp. 751-761.

Morris, M., Schindehutte, M. and Allen, J. (2005), "The entrepreneur's business model: toward a unified perspective", fournal of Business Research, Vol. 58 No. 6, pp. 726-735.

Mustak, M. (2014), "Service innovation in networks: a systematic review and implications for business-to-business service innovation research", fournal of Business \& Industrial Marketing, Vol. 29 No. 2, pp. 151-163.

Nyström, A.G. and Mustonen, M. (2017), "The dynamic approach to business models", AMS Review, Vol. 7 Nos 3/4, pp. 123-137.

O'Reilly, C.A., III. and Tushman, M.L. (2008), "Ambidexterity as a dynamic capability: resolving the innovator's dilemma", Research in Organizational Behavior, Vol. 28, pp. 185-206.

Osterwalder, A. and Pigneur, Y. (2010), Business Model Generation: A Handbook for Visionaries, Game Changers, and Challengers, John Wiley \& Sons.

Ottosson, M. and Kindström, D. (2016), "Exploring proactive niche market strategies in the steel industry: activities and implications", Industrial Marketing Management, Vol. 55, pp. 119-130.

Overholm, H. (2015), "Collectively created opportunities in emerging ecosystems: the case of solar service ventures", Technovation, Vols 39/40, pp. 14-25. 
Palo, T. and Tähtinen, J. (2011), "A network perspective on business models for emerging technology-based services", fournal of Business \& Industrial Marketing, Vol. 26 No. 5, pp. 377-388.

Palo, T. and Tähtinen, J. (2013), "Networked business model development for emerging technology-based services", Industrial Marketing Management, Vol. 42 No. 5, pp. 773-782.

Pateli, A.G. and Giaglis, G.M. (2005), "Technology innovation-induced business model change: a contingency approach", fournal of Organizational Change Management, Vol. 18 No. 2, pp. 167-183.

PA Consulting (2016), Innovation and the Next Generation Utility: embracing the New Energy Ecosystem, PA Knowledge, available at: paconsulting.com

Prenkert, F. (2017), "Understanding business networks from a mixed network and system ontology position", IMP fournal, Vol. 11 No. 2, pp. 301-326.

PwC Reports (2016), "Customer engagement in an era of energy transformation", available at: www.pwc.com/utilities

Ringberg, T., Reihlen, M. and Rydén, P. (2018), "The technology-mindset interactions: leading to incremental, radical or revolutionary innovations", Industrial Marketing Management, Vol. 79, pp. 102-113.

Saba, T. (2014), Clean Disruption of Energy and Transportation: How Silicon Valley Will Make Oil, Nuclear, Natural Gas, Coal, Electric Utilities and Conventional Cars Obsolete by 2030, Clean Planet Ventures, Silicon Valley, CA.

Sabatier, V., Craig-Kennard, A. and Mangematin, V. (2012), "When technological discontinuities and disruptive business models challenge dominant industry logics: insights from the drugs industry", Technological Forecasting and Social Change, Vol. 79 No. 5, pp. 949-962.

Santos-Vijande, M.L., González-Mieres, C. and LópezSánchez, J.Á. (2013), “An assessment of innovativeness in KIBS: implications on KIBS' co-creation culture, innovation capability, and performance", Fournal of Business E Industrial Marketing, Vol. 28 No. 2, pp. 86-102.

Sioshansi, F. (Ed.) (2014), Distributed Generation and Its Implications for the Utility Industry, 1st ed., Academic Press, Boston.

Sosna, M., Trevinyo-Rodríguez, R.N. and Velamuri, S.R. (2010), "Business model innovation through trial-and-error learning: the Naturhouse case", Long Range Planning, Vol. 43 Nos 2/3, pp. 383-407.

Storbacka, K., Windahl, C., Nenonen, S. and Salonen, A. (2013), "Solution business models: transformation along four continua", Industrial Marketing Management, Vol. 42 No. 5, pp. 705-716.

Teece, D.J. (2010), "Business models, business strategy and innovation", Long Range Planning, Vol. 43 Nos 2/3, pp. 172-194.

Teece, D.J. (2018), "Business models and dynamic capabilities", Long Range Planning, Vol. 51 No. 1, pp. 40-49.

Tikkanen, H., Lamberg, J.A., Parvinen, P. and Kallunki, J.P. (2005), "Managerial cognition, action and the business model of the firm", Management Decision, Vol. 43 No. 6, pp. 789-809.

Tongur, S. and Engwall, M. (2014), "The business model dilemma of technology shifts", Technovation, Vol. 34 No. 9, pp. 525-535.

Wang, Y.S. and Hsu, T.H. (2018), "Dynamic capabilities of biologics firms in the emerging business market: perspective of dynamic capabilities evident", Industrial Marketing Management, Vol. 71, pp. 5-18.

Windahl, C., Karpen, I.O. and Wright, M.R. (2020), "Strategic design: orchestrating and leveraging marketshaping capabilities", fournal of Business $\mathcal{E}$ Industrial Marketing, Vol. 35 No. 9, doi: https://doi.org/10.1108/JBIM03-2019-0133.

Yin, R.K. (2003), Case Study Research: Design and Methods, Sage Publication, Thousand Oaks.

\section{Further reading}

Murray, A., Skene, K. and Haynes, K. (2017), "The circular economy: an interdisciplinary exploration of the concept and application in a global context", fournal of Business Ethics, Vol. 140 No. 3, pp. 369-380.

Osterwalder, A., Pigneur, Y. and Tucci, C.L. (2005), "Clarifying business models: origins, present, and future of the concept", Communications of the Association for Information Systems, Vol. 16 No. 1, p. 1.

\section{Corresponding author}

Per Johan Carlborg can be contacted at: per.carlborg@oru.se 